\title{
Meeting Dividend Thresholds Through Earnings Management of Listed Companies in South Africa
}

\author{
Xin Yao $\mathrm{Li}^{1}$ and Pei-Wen Chen ${ }^{2}$
}

\begin{abstract}
Dividend distribution influences corporate operating decisions, and the prior year's dividends represent an earnings threshold. The purpose of this study was to clarify perceptions regarding the manipulation of income toward a desired earnings goal (i.e., dividend threshold). In this study, data from 2011 to 2019 were collected from the S\&P Capital IQ database. A regression model was adopted to analyze the manipulation of income toward a dividend threshold (i.e., desired earnings goal) among South Africa's listed industry. Moreover, the behavior of managers of listed South African firms tended to meet or exceed dividend thresholds by manipulating earnings, which is consistent with signal theory, prospect theory and agency theory.
\end{abstract}

Keywords: Dividend thresholds, Earnings management, South Africa, Signal theory, Prospect theory.

1 Department of accounting, School of Business, Changzhou University.

2 Department of accounting, School of Business, Changzhou University. 


\section{Introduction}

When businesses lack funds, they may need to obtain external financing. In general, they can obtain funds through issued stocks or borrow from debtors such as individuals, other enterprises, or financial institutions. If a business chooses to obtain funds through issued stocks, they should consider approaches to providing returns to stockholders. Paying cash dividends to shareholders is a common approach. A firm's propensity to pay dividends and level of dividend payments are also likely to be influenced by excessive earnings retention (Bae et al., 2012; Shao et al., 2009; Fidrmuc \& Jacob, 2010), thus managers often strive to avoid dividend cuts (Lintner, 1956) because dividends are more responsive to reported earnings (Dewenter and Warther,1998). A large negative stock market reaction also leads to dividend decreases (DeAngelo and DeAngelo's, 2006a; Kallapur,1994; Grullon et al.,2002). Furthermore, (Miller and Modigliani 1961) reported that dividend decrease is an unfavorable predictor. Grullon et al. (2002) and Lie (2005a, b) reported that earning decline foreshadows dividend cuts possibly because of declining earnings depleting the resources needed for continued operations and a healthy balance sheet. Cutting dividends naturally offsets this depletion; low earnings can trigger violations of dividend covenant restrictions, which would require a cut in dividends. Overall, the importance of payout policies for firms (as signaling mechanisms, for firm health, and as violations of dividend covenant) that payout threshold analysis is critical.

Earnings management is subjective because managers can adjust financial reports and structure transactions to mislead stakeholders about the economic performance of a company or influence contractual outcomes that depend on reported accounting numbers (Healy and Wahlen, 1999). Prior literature also shows that managers can manage earnings in two different ways. First, managers can exercise discretion over accrual choices that are allowed under Generally Accepted Accounting Principles to reach a desired level of earnings (referred to as accrual-based earnings management, AEM). The method measures discretionary accruals using some firmspecific characteristics. Second, managers can manage earnings by altering the timing and scale of operating decisions (referred to as real activities based earnings management, REM). Other researchers argue that to change reported earnings, managers do not necessarily resort to playing around with accounting methods and estimations, rather they or could change real operation decisions, such as cash flow from operations, production costs, and discretionary expenditures (Roychowdhury, 2006), sales manipulation (Ge \& Kim, 2014; Stubben, 2010). Moreover, firms' levels of dividend payments are likely to be influenced by the current year's earnings and retained earnings. Therefore, a firm's dividend policy and level of dividend incentive likely affect earnings. Studies (Lintner, 1956; Watts and Zimmerman, 1986; Kasanen et al., 1996; Grullon et al., 2002; Brown and Caylor, 2005; Daniel et al., 2008; Atieh et al., 2012; Liu and Espahbodi, 2014) have revealed that managers manipulate earnings according to the level of dividend because owners prefer stable dividends. Thus, managers will maintain consistency 
with their past dividend policies (i.e., where pre-managed earnings below the expected dividend and firms aiming for an upward earning management avoid reporting lower than expected dividend).

Most studies have focused on maintaining stable dividends by manipulating earnings among accrual, which resulted in meeting or exceeding dividend thresholds. However, the related studies have not considered the effects that an emerging economy may have on these situations. South Africa is a major emerging country and a BRICS member. It also has a relatively high gross domestic product (GDP) per capita compared with other countries in sub-Saharan Africa.

Those features raise many interesting questions for researchers and policy makers. In this report, we review the listed companies in South Africa. Using company level data, we will study to clarify perceptions regarding the manipulation of income through real activities based earnings management (REM) toward a desired earnings goal (i.e., dividend threshold). The goal is to provide a picture of this industry about its current situations, and its transformation and trends, using both industry level data and firm level data.

This paper contributes to the literature on the criteria influence management's preferences for an earnings threshold and adopts the aforementioned theories (i.e., prospect theory, signaling theory and agency theory). We examined managers make decisions by focusing on the value from gains (i.e., dividend thresholds) with a certain reference point (i.e., the prospect theory) or signals and agency. The remainder of the paper is organized as follows. Section 2 presents a brief review of the related literature. Section 3 details the research design, sample selection procedure, and model development. Section 4 presents our empirical findings. Section 5 contains a summary and conclusion.

\section{Literature Review}

\subsection{Earnings management}

Farrell et al. (2013) determined that growth firms are less likely to use share repurchases to increase EPS for earnings management and also provided evidence that firms with a more independent board, a separation of the roles of CEO and chairman of the board, or a low entrenchment index (E-Index) are less likely to engage in earnings management through share repurchases. These findings suggest that strong corporate governance, strong shareholder rights, and high percentage CEO stock ownership discourage repurchase-based earnings management. Doukakis 2014) suggested that mandatory IFRS adoption had no significant effect on either real or accrual-based earnings management (AM) practices in 22 European countries between 2000 and 2010 because of a dominant role for firm-level reporting incentives over accounting standards in shaping financial reporting quality. Kuang et al. (2014) reported that outside CEOs engaged in greater incomeincreasing manipulation in the early years of their tenure, but differences in earnings management practices became non significant after the CEO had been employed for a certain amount of time. This may be because CEOs recruited from outside 
have a stronger incentive to demonstrate their abilities in the initial years after their appointment. Outside CEOs may also have lower expectations of survival in the short-term. Shu and Chiang (2014) proposed that large and small firms listed on the Taiwan Stock Exchange treat their seasoned equity differently. They showed that, for small firms, the timing effect is positively (negatively) correlated with firms' short-term (long-term) wealth, whereas for large firms, earnings management (proxied as DAs gauged by the modified Jones model) is positively (negatively) correlated with short-term (long-term) wealth.

Zhu et al. (2015) determined that Chinese RM firms engaged in both real activities and accrual-based manipulations at higher levels than non-Chinese RM firms, regular US firms, and other Chinese US-listed firms. Big 4 auditors can effectively constrain real activities and AM in Chinese RM firms, particularly in firms that used real activities and accrual-based manipulation as substitutes and transitioned to real activity management in the years after a reverse takeover. Ho et al. (2015) observed that Chinese firms in the post-IFRS period (2007-2011) were less likely to engage in AM. However, the new reform also produced a set of new auditing standards and internal control reporting requirements so the magnitude of discretionary accruals also decline. Razzaque et al. (2016) revealed that in Bangladesh, family firms engaged in more REMs compared with nonfamily firms during 2006-2011, with REM associated with lower future performance. Commerford et al. (2016) revealed that REM is a significant source of auditor discomfort and that auditors use both their rationality and their emotions to identify and alleviate that discomfort because they believed that it is indicative of the management's desire to meet short-term targets (i.e., poor management tone) and that it might have indicated the use of other less-acceptable earnings management methods (i.e., accruals-based earnings management) to meet these targets. Francis et al. (2016) suggested that the legal environment is crucial in a firm's choice of earning management techniques and revealed that RM increases with country-level legal strength as a stronger legal system discourages AM. Cheng et al. (2016) determined that the extent of REM decreases when key subordinate executives' influence and internal governance is stronger for firms with more complex operations, is enhanced when CEOs are less powerful, is weaker when the capital markets benefit of meeting or beating earnings benchmarks is higher and is stronger in the post-SOX period.

Mellado-Cid et al. (2017) reported that bond-issuing firms increases their real activities manipulation in the five quarters leading to bond issuance. They also reported an inverse association between yield spread and preissue real activities manipulation (i.e., firms engaged in abnormally high levels of real activities manipulation are associated with a subsequent lower cost of debt). Huang et al. (2017) demonstrated that an increase in stock liquidity is associated with an increase in discretionary accruals and revenue because liquidity affects earnings management by magnifying the effects of takeover pressure and equity compensation. Greiner et al. (2017) reported that with the exception of abnormal reductions in SG\&A, aggressive income-increasing REM is positively associated with both current and future audit fees because REM are considered in auditors' 
assessments of engagement risks related to the client's economic condition, resulting in higher audit fees. Therefore, increased effort and increased risk are contributing to the current pricing effect, with increased business risk primarily driving the future pricing effect. Anagnostopoulou and Tsekrekos (2017) revealed that leverage levels and increases positively and significantly affect upward RM, without significant effects on income-increasing AM, whereas our findings suggested a complementarity effect between unexpected levels of RM and AM for firms with very high leverage levels and changes. This is interpreted as an indication that high leverage could attract heavy outsider scrutiny, making it necessary for firms to use both forms of earnings management to achieve earnings targets.

Beyer et al. (2018) reported that the positive relation between REM and future profitability was limited to firms that had less robust information environments, more costly REM, and fewer incentives to meet short-term earnings benchmarks (measured with market-to-book ratio, transient investors, and seasoned equity offering). Haga et al. (2018) noted that public firms engage in more earnings management through operating activities and public firms manage their earnings more than private firms because capital market pressure and ownership characteristics drive our results. Kim et al. (2018) reported that in Korean firms, an increase in the largest shareholders' ownership is negatively related to REM in the quarters preceding an SEO and that positive market response to SEO with the largest shareholders' ownership increases are mitigated by the level of REM.

Liu et al. (2019) used a panel data set of Chinese public firms and demonstrated that there is more prominent decrease or increase in accrual or real earnings management in short-selling firms. Mellado-Cid et al. (2019) investigated REM's uncertainty in the value of a firm's common stock and the resulting increased volatility spread and skew of the firm's options. Pham et al. (2019) observed that discretionary accruals are insignificantly related to contemporaneous stock returns. Li et al. (2019) demonstrated that CEO equity compensation is positively associated with both AM and REM and the relation between AM and REM for firms is complementary rather than a tradeoff.

\subsection{Earnings thresholds}

Prior research has also suggested that firm stakeholders use earnings benchmarks as references to evaluate firm performance. Firms thus have strong incentives to manage their earnings to meet or exceed earnings benchmarks, the earnings of the positive earnings ( $\mathrm{Li}, 2010)$, analyst forecasts (Athanasakou et al.,2011) and prior year (Macgregor,2012). Li (2010) found that large firms, firms with high growth prospects, and firms with high trading volume are more concerned with avoiding unanticipated negative earnings. Athanasakou et al., (2011) indicated that UK firms use earnings forecast guidance and classification shifting to achieve analyst expectations. However the market does not reward firms that achieve expectations through forecast guidance, and achievers that shift classifications receive lower market rewards than genuine achievers. Macgregor (2012) found that the influence 
of audit committee equity holdings on the likelihood that a firm meets the prior year's earnings varies with the CEO's equity incentives and level of high-risk assets because the expected benefits of affording the discretion are greater (less) than the expected costs of the reporting problems that might occur from affording the discretion.

Furthermore, (Chen et al. 2010) measured the frequency and magnitude of earnings management assuming earnings follow a mixed-normal distribution and they revealed that the frequency of earnings management is the highest when firms attempted to meet analysts' forecasted earnings; firms generally manage earnings to avoid earnings decreases rather than to avoid negative earnings. Eames \& Kim (2012) reported that analysts exhibit more forecast optimism in their zero earnings forecasts than in their other small earnings forecast levels, whereas markets display less relative optimism because they do not follow analysts in erroneously predicting earnings management to avoid small losses. Ferreira et al. (2013) demonstrated that political competition is a determining factor in earnings management when earnings are positive but close to zero. Discretionary accruals are used because of the overriding tendency to avoid reporting losses in municipalities with a higher level of political competition. Liu et al. (2014) identified that firms with an accounting expert serving on the audit committee exhibit:

1) less expectation management to avoid negative earnings surprises;

2) less nonnegative earnings surprises through expectations management; and

3) more nonnegative earnings surprises that are less susceptible to manipulation due to realized earnings and earnings expectations.

Dinh et al. (2016) collected samples of highly R\&D intensive German IFRS firms during 1998-2012 and identified firm years for which R\&D capitalization was possibly used for pushing their earnings above a specific threshold (e.g. analysts' forecasted earnings, prior year's earnings). Discretionary R\&D capitalization can be exercised by managers to signal private information on future economic benefits to the market, meaning that the decision to capitalize and how much to capitalize are strongly associated with benchmark beating. Dumas (2017) reported that R\&D spending was capitalized to meet these thresholds, and managers reduce $R \& D$ to meet earnings thresholds (zero earnings and prior year earnings) and these earnings management techniques are substitutes for each other. Kent and Routledge (2017) used accrual quality models, earnings distributions, and earnings persistence to measure manipulated earnings. They suggested that the small positive earnings benchmark attracted earnings managers but did not provide any evidence to indicate that the positive earnings change benchmark was a predictor for earnings management within the Australian market. Halaoua et al. (2017) analyzed the manner in which French and British firms manage their earnings, revealing that all firms considered managing earnings to beat zero or the previous year's earnings. However, earnings management to meet analysts' forecasts appeared to be more prevalent in British firms. Carvajal et al. (2017) demonstrated that analysts' earnings forecast is at the top of the earnings benchmark in Australian firms without analyst coverage; thus, the reporting of positive earnings is the predominant 
earnings benchmark. Callao and Ignacio Jarne (2018) reported that earnings forecasted by analysts constitute an incentive to manage the earnings Figure upwards, but they did not find evidence of the incentive to manage earnings downward to avoid exceeding analysts' forecasts, thereby avoiding subsequent forecasts that are more difficult to achieve. Canace et al. (2018) noted that firms narrowly achieving earnings thresholds also report unusually high capital expenditures. Furthermore, these firms' total investments (R\&D expense plus capital expenditures) do not vary in response to earnings thresholds, suggesting that on average, reductions in $R \& D$ expenses are offset by concurrent increases in capital expenditures.

\subsection{Earnings management and dividends threshold}

Lintner (1956) first study of dividend policy revealed that managers are reluctant to cut dividends and willing to increase them only gradually after they are convinced that this increase will result in a higher level of dividends by increasing future earnings. Bennet \& Bradbury (2007) proposed considering dividend cover as a threshold because firms are likely to manage earnings to avoid cutting dividends (i.e., maintaining dividend value from the prior year). Daniel et al.,(2008) and Atieh et al.,(2012) also found that dividend-paying firms tend to manage earnings when pre-managed earnings are below expected dividend levels (prior year's dividends) because firms tend to cut dividends when reported earnings fall below the level of prior dividends.

Signaling theory states that signals are informational cues sent out by one party to another to influence desired outcomes. Consequently, insiders focus on sending out positive signals to outsiders and avoid sending negative information to reduce information asymmetry, which helps firms reach their ultimate goal of positively influencing their desired outcome (Taj, 2016). Furthermore, the signaler (i.e., insiders) should receive some benefit from the receiver that the receiver would not usually provide (i.e., signaling should have a strategic effect); this benefit usually involves selecting the signaler in favor of alternatives (Connelly et al., 2011). Artikis et al. (2010) demonstrated that higher levels of accounting information disclosure produce a reduction of the market's perception of the risk associated with stock returns, which in turn leads to a lower premium for marketed securities because improved accounting information affects the firm's real decisions; investors can better assess the future potential course of the firm.

In addition, managers may exercise discretion over earnings to communicate private information to stockholders and the public (Arya et al., 2003; Demski, 1998). Grullon et al. (2002) also reported the importance of maintaining a historical dividend level and payout ratio because of the large negative stock market reaction to unexpected dividend decreases or omission, and the stock market's perception of the value relevance of dividends. Brav et al. (2005) indicated that approximately $90 \%$ of dividend-paying firms strive to avoid dividend reductions and to smooth dividend streams from year to year because managers believe that dividend 
decisions convey information to the market and thus have negative consequences. Furthermore, Halaoua et al. (2017) revealed that managers who convey their private information to investors reduce information asymmetry regarding future firm prospects and increase willingness to sustain future performance by manipulating earnings to achieve a certain earnings level threshold. Thus, managers may exercise discretion over earnings maintained at the level of dividend-paying to communicate private information with stockholders and the public. We propose the following hypothesis:

H1: firms are likely to meet/beat dividend thresholds through earnings management with signaling theory

Kahneman and Tversky (1979) presented prospect theory and reported that managers making decisions focus on the value with a certain reference point. Baker et al. (2001) determined that the desire to maintain a dividend payout ratio is a moderately important factor relative to dividend level in determining dividend policy. Approximately half of the responding firms had explicit target payout ratios. On the other hand, achieving a certain value potentially reduce information asymmetry regarding the firm's future prospects and managers' willingness to sustain future performance. Consequently, managers also tend to frequently manage earnings, possibly enabling them to meet or exceed earnings thresholds (i.e., dividend thresholds).

H2: firms are likely to meet/beat dividend thresholds through earnings management with prospect theory

Agency theory explains that principals and agents have different purposes; consequently, they have a conflict of interest. Meini and Siregar (2014) noted that managers have more information than external parties, such as investors and creditors, and their information is faster and more detailed; thus, information asymmetry provides incentives to management to manipulate earnings to maximize their own welfare. Additionally, (Ifada and Wulandari 2015) demonstrated that conflicts of interest between parties arise when a company demands a certain profit level. By contrast, (Namazi 1985) argued that agency theory assumes both individuals are risk averse because an agency operates under conditions of risk and uncertainty; therefore, the amount and content of the produced accounting information become a sizable hurdle in risk sharing and controlling of an agent's actions. According to agency theory, this action may reflect a conflict of interest between the principal (i.e., outsiders) and the agent (i.e., insiders) because of information asymmetry threshold. Consequently, managers also tend to obtain private benefits by manipulating a certain profit target possibly enabling them to meet or exceed earnings thresholds (i.e., dividend thresholds). 
H3: firms are likely to meet/beat dividend thresholds through earnings management with agency theory.

\section{Methodology}

This subsection briefly describes the construction of our sample and key variables. We obtain financial data from S\&P capital IQ. Our sample period spans from 2011 to 2019. To be included in the sample, we require that (i) a firm must have nonmissing accounting data for calculating earnings management measures or dividend variables. These requirements result in 121 firm-year or quarterly observations for 603 samples. Specifically, our samples in South Africa are classified as being in the following sectors: financials $(23.14 \%)$, materials $(17.35 \%)$, industrials $(15.70 \%)$, real estate $(12.39 \%)$, consumer discretionary $(9.09 \%)$, consumer staples $(7.44 \%)$, information technology $(4.95 \%)$, health care $(4.13 \%)$, communication services $(3.31 \%)$, utilities $(1.65 \%)$, energy $(0.82 \%)$. The variables and research model of this study are as follows.

\subsection{Earnings management: real activities earnings management}

Roychowdhury (2006) demonstrated that real activities earnings management and developed the following regression models to estimate the typical levels of real business activities. The absolute value of $\varepsilon$ originates from the following model that measures real activities earnings management (i.e., the abnormal level). In addition, we used the absolute value of $\varepsilon$ multiplied by the assets for the year $t-1$ to reflect the real numbers. A regression model was adopted to analyze the data.

$$
\frac{C F O_{i t}}{T A_{i t-1}}=\alpha_{0} \frac{1}{T A_{i t-1}}+a_{1} \frac{S A L E S_{i t}}{T A_{i t-1}}+\alpha_{2} \frac{\Delta S A L E S_{i t}}{T A_{i t-1}}+\varepsilon_{i t}
$$

where $C F O_{i t}$ is the cash flow form operations for year $\mathrm{t}$; $T A_{t-1}$ is the assets for year $\mathrm{t}-1$; $S A L E S_{i t}$ is the sales for year $\mathrm{t} ; \triangle S A L E S_{i t}$ is the change in sales for year $\mathrm{t}$.

We define total real earnings management as the sum of abnormal cash flow form operations (Liu et al.2014).

\subsection{Dividend thresholds}

Daniel et al., (2008) found that "expected dividends" represent an earnings threshold. They defined a firm's expected dividend as the prior year's dividend (the term "dividend" refers to regular cash dividend payments by firms). We followed it and revised pre-managed earnings as pre-managed operating cash flow minus preferred dividends. We defined dividend thresholds as being exceeded when managed earnings (pre-managed operating cash flow plus discretionary operating cash flow) are higher than expected dividend payments. 


\subsection{Model}

We examined the frequency distribution of earnings by using the approach of (Burgstahler and Dichev 1997) ${ }^{3}$, who established the importance of earnings thresholds by examining the frequency distribution of earnings near a relevant threshold. This approach involves testing for earnings management by observing the outcome of earnings management rather than seeking direct evidence of earnings management by analyzing REM. In this approach, expected earnings represent critical earnings thresholds, and an abnormally high number of firms report earnings marginally above the threshold.

\section{Empirical results}

\subsection{Descriptive statistics}

Table 1 pointed that the regressions results of cash flow from operations model. Table 2 showed that the estimated cross-section of the discretionary of s cash flow from operations (all of $\varepsilon_{i t}$ is measured by equation 1 have been passed T-test),the mean of cash flow from operations are positive is positive, indicating that listed companies in South Africa have adopted discretionary cash flow from operations to earnings management to increase their adjusted income.

Table 1: Regressions of Roychowdhury (2006) model

\begin{tabular}{|c|c|}
\hline \multicolumn{2}{|c|}{ Dependent variable: $\frac{C F O_{i t}}{T A_{i t-1}}$} \\
\hline$\frac{1}{T A_{i t-1}}$ & $0.196^{* * *}$ \\
\hline$\frac{S A L E S_{i t}}{T A_{i t-1}}$ & 0.017 \\
\hline$\frac{\Delta A L E S_{i t}}{T A_{i-1}}$ & -0.005 \\
\hline $\mathrm{R}^{2}$ & 0.034 \\
\hline F value & 8.084 \\
\hline
\end{tabular}

Note: $C F O_{i t}$ is the cash flow from operations for year t; $S A L E S_{i t}$ is the sales for year $\mathrm{t} ; \quad \triangle S A L E S_{i t}$ is the change in sales for year $\mathrm{t} ; A_{i t-1}$ is the assets for year $\mathrm{t}-1$. $*: \mathrm{p}<0.1 、 * *: \mathrm{p}<0.05 、 * * *: \mathrm{P}<0.01$

\footnotetext{
${ }^{3}$ This method shows the distribution of earnings scaled by the beginning-of-period market value of equity, and we redefine distribution of earnings as the "managed earnings" minus expected dividend payments scaled by the beginning-of-period market value of equity. (the approach of Burgstahler and Dichev, 1997).
} 
Table 2: Descriptive statistics of the discretionary of cash flow from operations

\begin{tabular}{|c|c|c|c|}
\hline \multicolumn{4}{|c|}{ (Million, US dollars) (N=603) } \\
\hline & Max & Min & Avg \\
\hline$D C F O_{i t}$ & 8218.14 & -8074.23 & 116.8057 \\
\hline
\end{tabular}

where denotes the $D C F O_{i t}$ of the Roychowdhury (2006) model for year $\mathrm{t}$ (equation 1).

\subsection{Empirical Test}

We divided scaled earnings from -0.2 to +0.2 into intervals with a 0.005 width (consistent with the study by Burgstahler and Dichev, 1997) ${ }^{4},{ }^{5}$. This is illustrated in Figure 1 and Figure $2^{6}$ which indicate a standardization difference between the negative value to the left of zero and the positive value to the right of zero, and this result is consistent with that of El- Sayed Ebaid (2012). Figure 1 shows that managers in South Africa listed industry not tend to meet or exceed dividend thresholds (they pass the normal distribution test) with premanaged earnings, and most of our sample is less the dividend thresholds. Figure 2 also shows that managers tend to meet or exceed dividend thresholds (they pass the normal distribution test) with managed earnings, and most of our sample is above the dividend thresholds.

Therefore, these empirical findings revealed that firms, to avoid dividends, decreased their earnings. This is also consistent with Daniel et al. (2008) and Bennet and Bradbury (2007). Moreover, we noted that dividend policies are crucial role in accounting policy in South African listed firms because dividends are likely to be a benchmark for investors. Therefore, they may avoid sending negative information to outside investors and thus may achieve a certain earnings level threshold (i.e., the past level of dividend), which enables firms to reach their goal of positively influencing their desired outcome and convey their private information to investors or capital market to reduce information asymmetry regarding future firm prospects; this increases willingness to sustain future performance and leads managers to engage in earnings management to avoid cutting dividends by distorting accounting numbers to achieve the desired image. This observation is consistent with signaling theory that signals are informational cues sent out by one party to another to

\footnotetext{
${ }^{4}$ Burgstahler and Dichev (1997) assumed that if the examined cross-sectional distribution is relatively smooth, the test statistic is given.

5 This are illustrated in Figure 1-2, which indicate a standardization difference between the negative value to the left of zero and the positive value to the right of zero, and this result is consistent with that of El- Sayed Ebaid (2012).

6 Our initial sample number was 603; therefore, we followed Burgstahler and Dichev's (1997) approach and deleted samples wait scaled earnings above 0.2 and below -0.2 . Finally, 571 and 481 samples were included in Figure 1 and Figure 2, respectively.
} 
influence desired outcomes. The signals are primarily positive. Thus firms are likely to meet or beat dividend thresholds through real activities earnings management such as operating cash flows with signaling theory. Therefore, H1 is supported. In addition, prospect theory suggests that managers make decisions based on value, employing a certain reference point.

Kahneman and Tversky (1979) reported that when making decisions, managers focused on the value from gains or losses with a certain reference point rather than levels of wealth. Therefore, our empirical results demonstrated that the listed firms in South Africa meet or exceed dividend thresholds through manipulating earnings using operating cash flows because they focus primarily on whether expected dividend levels can be above past dividend levels (value from gains or losses of a certain reference point), rather than on how much dividends can be obtained by manipulating earnings through operating cash flows (the levels of wealth of a certain reference point). Therefore, our study also supports the theory that the desire to maintain a dividend payout level is a measure of earnings benchmarks and may be considered to be consistent with this theory. Therefore, $\mathrm{H} 2$ is supported.

Agency theory explains that principals and agents have different purposes; consequently, they have a conflict of interest. Meini and Siregar (2014) noted that managers have more information than external parties, such as investors and creditors, and their information is faster and more detailed; thus, information asymmetry provides incentives to management to manipulate earnings to maximize their own welfare. Additionally, Ifada and Wulandari (2015) demonstrated that conflicts of interest between parties arise when a company demands a certain profit level. Thus firms are likely to meet or beat dividend thresholds through real activities earnings management such as operating cash flows. Therefore, our study also supports the theory that the desire to maintain a dividend payout level is a measure of earnings benchmarks and may be considered to be consistent with this theory. Therefore, H3 is supported. On the other hands, we use only samples containing data from the 5 th to the 95th percentiles as measures for the robustness test to avoid possible bias from extreme values, and the results show that most of them are consistent. To shorten the tables, we omit the solution. 


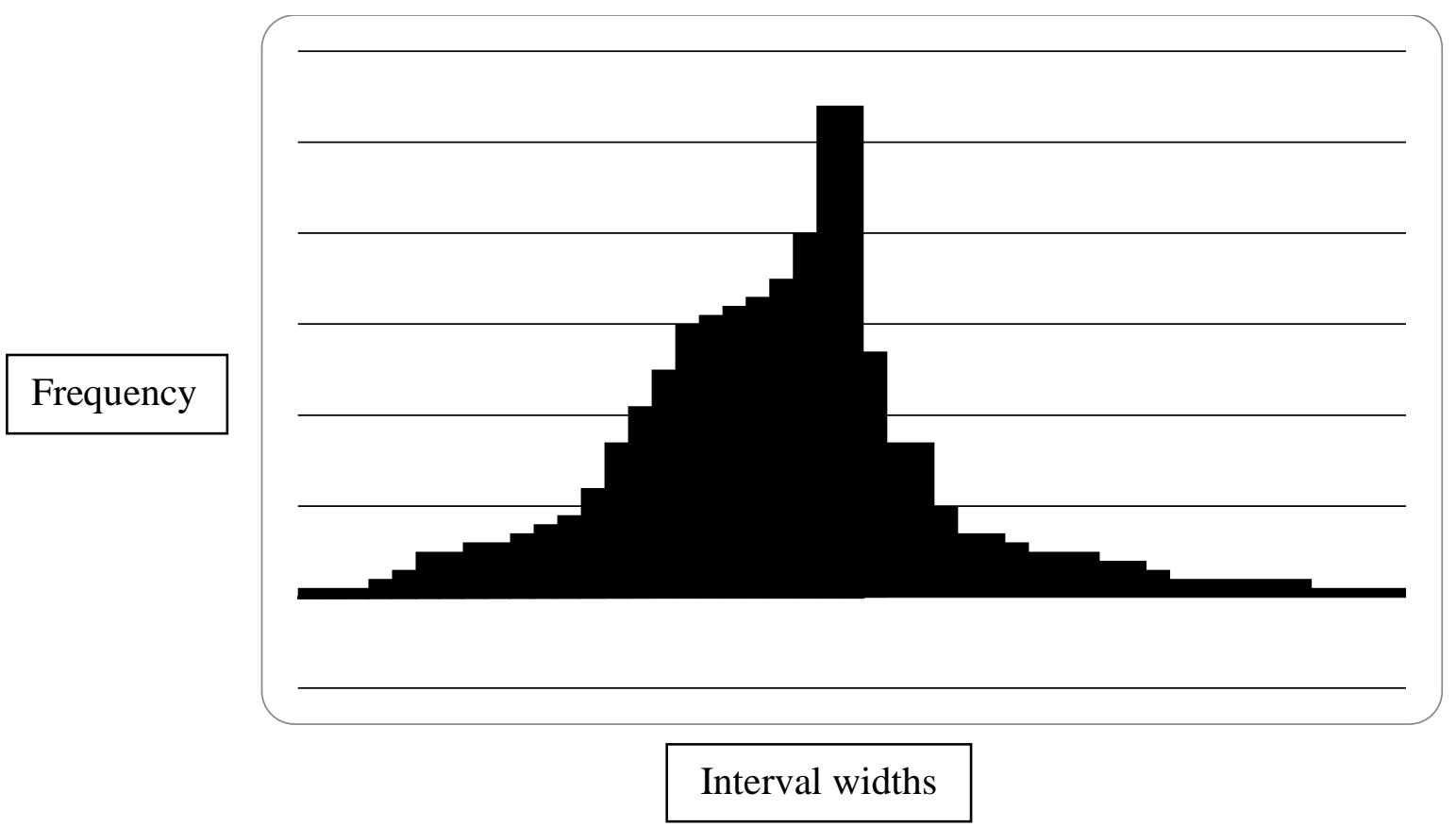

Figure 1: Distribution of meeting dividend thresholds through pre-managed earnings $(\mathrm{N}=571)$

Frequency

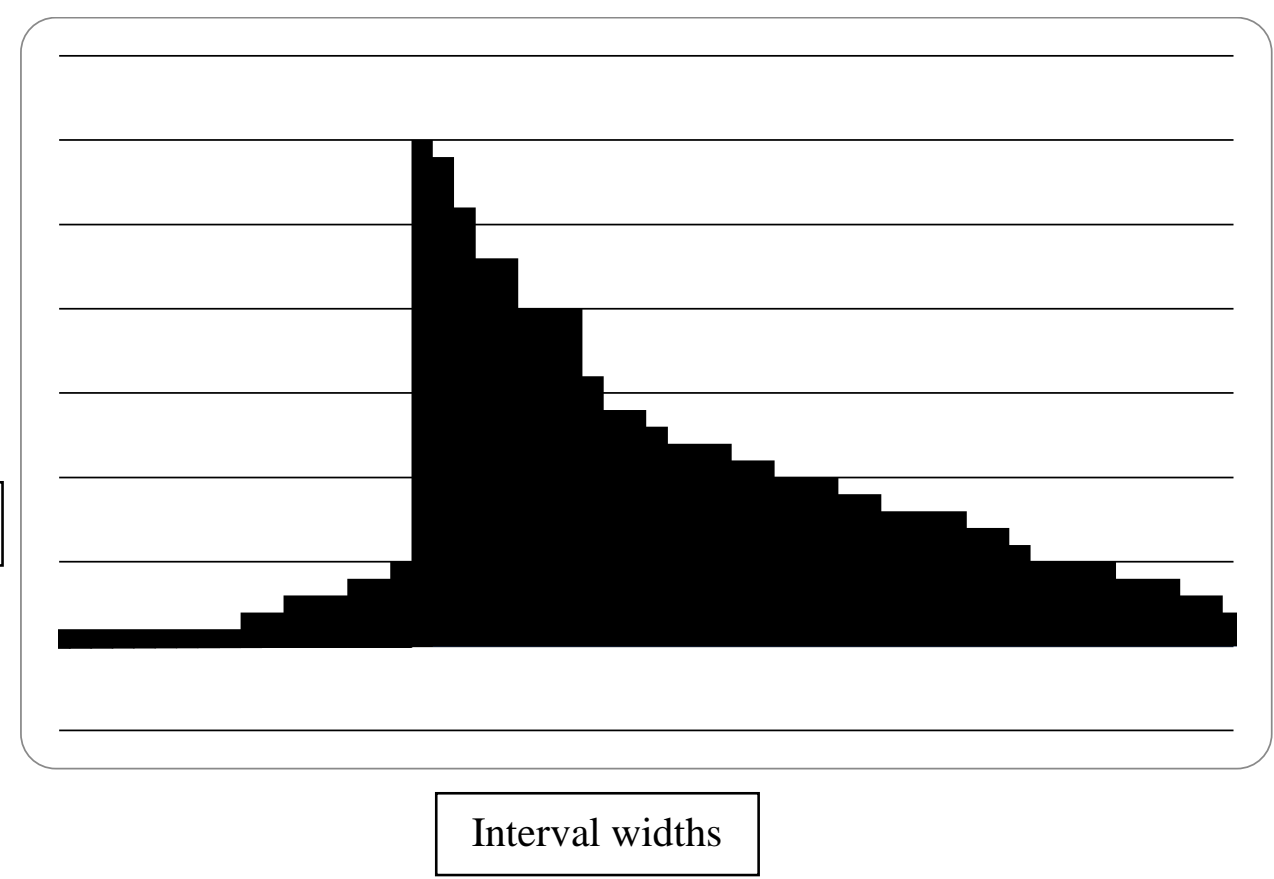

Figure 2: Distribution of meeting dividend thresholds through managed earnings $(\mathrm{N}=481)$ 


\section{Conclusion}

The presented results of our analysis proved the hypothesis that firms are likely to meet/beat dividend thresholds through earnings management in South Africa listed industry. These findings contribute to the growing literature on international differences in earnings management practices and emphasize the strong and direct effect of industry on meeting or exceeding dividend thresholds through earnings management over multiple years. In addition, signal, prospect and agency theory are also supported because the managers of South Africa listed firms tend to meet or exceed dividend thresholds through earnings management.

However, this study has limitations. Dividends are almost always issued as cash dividends (i.e., repurchases and stock dividends may also be issued). Therefore, operating cash flows may not represent the overall dividend threshold, and researchers could stress the importance of firms' payout components. Additionally, we used real activities to measure earnings management, and different models to measure REM revealed different results. Therefore, tradeoff tools should be used to examine earnings management among managers to ensure the robustness of our results. In future studies, the effect of national acts and their implementation on the optimal dividends level should be considered. Data from enterprises should be collected to conduct empirical analyses on the influencing factors of the dividend thresholds, such as economic development, geographical location, and culture. In addition, our empirical results suggest that investors evaluate firm performance (i.e., earnings) before dividends are paid, which should be noted by financial market participants and regulators when assessing financial statements and the reliability of financial reporting. Thus, governments should strengthen corporate governance, strictly control the disclosure principle of the financial report of listed firms, reduce information asymmetry in the capital market (i.e., principal-agent problems), improve stock market efficiency, and optimize financial environment structure. 


\section{References}

[1] Anagnostopoulou, S. C.and Tsekrekos, A. E. (2017). The effect of financial leverage on real and accrual-based earnings management. Accounting And Business Research,47(2): 191-236

[2] Artikis,G., Eleftheriou,S. and Sorros, J. (2010). Accounting Information and the Cost of Capital: The Effect on Excess Stock Returns-Evidence from Panel Data. Journal of Business and Economics, 1(1):54-66

[3] Arya, A., Glover, J. and Sunder, S. (2003). Are unmanaged earnings always better for shareholders? Accounting Horizons, 111-116 (supplement).

[4] Atieh, A. and Hussain, S. (2012). Do UK Firms Manage Earnings to Meet Dividend Thresholds? Accounting and Business Research, 42(1), 77-94.

[5] Athanasakou, V., Strong.N. C. and Walker, M.(2011). The Market reward for achieving analyst earnings expectations: does managing expectations or earnings matter? Journal of Business Finance and Accounting, 38(1) \& (2): 5894.

[6] Bae, S.C., Chang, K. and Kang, E.(2012). Culture, corporate governance, and dividend policy: international evidence. Journal of Financial Research 35, 289316.

[7] Baker, H., Veit E. and Powell, G. (2001). Factors Influencing Dividend Policy Decisions of NASDAQ Firms. The Financial Review,36, 19-38.

[8] Bennet, B. and Bradbury, M.E.(2007).Earnings thresholds related to dividend cover. Journal of international accounting and research, 6(1):1-17.

[9] Beyer, B. D.; Nabar, S. M. and Rapley, E.T. (2018). Real Earnings Management by Benchmark-Beating Firms: Implications for Future Profitability. Accounting Horizons, 32(4):59-84.

[10] Brav, A., Graham, J., Harvey, C. and Michaely, R. (2005). Payout Policy in The 21st Century. Journal of Financial Economics, 77, 483-527.

[11] Brown, L.D. and M.L. Caylor(2005). A temporal analysis of quarterly earnings thresholds: Propensities and valuation consequences. Account. Rev., 80: 423440

[12] Burgstahler, D. and Dichev, I.(1997).Earnings management to avoid earnings decreases and losses. Journal of Accounting and Economics, 24:99-126.

[13] Callao, S. and Ignacio Jarne, J.(2018). Analysts' forecasts as an incentive for earnings management. Spanish Journal of Finance and Accoutning-Revista Espanola De Financciacion Y Contabilida,47(1):124-155.

[14] Carvajal, M., Coulton, J. J. and Jackson, A.B. (2017). Earnings benchmark hierarchy. Accounting and Finance, 57(1):87-111

[15] Chen, S.K.; Lin, B.X. and Wang, Y. (2010). The frequency and magnitud-e of earnings management: Time-series and multi-threshold comparisons. International Review of Economics \& Finance, 19(4): 671-685.

[16] Cheng, Q.,Lee, J. and Shevlin, T.(2016). Internal Governance and Real Earnings Management. Accounting Review, 91( 4): 1051-1085 
[17] Commerford,B.P., Hermanson, D.R. and Houston, R. W. (2016). Real Earnings Management: A Threat to Auditor Comfort. Auditing-A Journal of Practice \& Theory, 35(4): 39-56.

[18] Connelly,B.L.,Certo,S.,Ireland,R.D. and Reutzel,C.R.(2011). Signaling Theory: A Review and Assessment. Journal of Management,37(1):39-67

[19] Daniel, N., Denis, D. and Naveen, L.(2008). Do firms manage earnings to meet dividend thresholds? Journal of Accounting and Economics, 45: 2-26

[20] Deangelo, H. and Deangelo, L. (2006). The irrelevance of the MM dividend irrelevance theorem. Journal of Financial Economics, 79: 293-315.

[21] Demski, J. (1998). Performance measure manipulation. Contemporary Accounting Research, 15:261-285.

[22] Dewenter, K. and Warther, V.(1998). Dividends, asymmetric information, and agency conflicts: evidence from a comparison of the dividend policies of Japanese and U.S. firms. J. Financ. 53, 879-904.

[23] Dinh, T., Kang, H. and Schultze, W. (2016). Capitalizing Research \& Development: Signaling or Earnings Management. European Accounting Review,25(2):373-401.

[24] Doukakis, L. C. (2014). The effect of mandatory IFRS adoption on real and accrual-based earnings management activities. Journal of Accounting and Public Policy, 33(6):551-572.

[25] Dumas, G.(2017). Processual earnings management: A study of R\&D spending of french listed companies. Comptabilite Controle Audit, 23(2):111141.

[26] Eames, M. and Kim, Y. (2012). Analyst vs. Market Forecasts of Earnings Management to Avoid Small Losses. Journal of Business Finance \& Accounting,39(5-6):649-674.

[27] El-Sayed Ebaid, I.(2012). Earnings management to meet or beat earnings thresholds evidence from the emerging capital market of Egypt. African Journal of Economic and Management Studies,3(2), 240-257.

[28] Farrell, K.,A.,Yu, J. and Zhang, Y.(2013). What are the Characteristics of Firms that Engage in Earnings Per Share Management Through Share Repurchases? Corporate Governacne-An International Review,21(4):334-350.

[29] Ferreira, A., Carvalho, J. and Pinho, F.(2013). Earnings management around zero: a motivation to local politician signalling competence. Public Management Review, 15(5):657-686.

[30] Fidrmuc, J.P. and Jacob, M.(2010). Culture, agency costs, and dividends. Journal of Comparative Economics 38(3), 321-339.

[31] Francis, B., Hasan, I. and Li, L.,(2016). A cross-country study of legal-system strength and real earnings management. Journal of Accoutning and Public Policy, 35(5): 477-512.

[32] Ge,W.X. and Kim, J.B. (2014). Real earnings management and the cost of new corporate bonds. Journal of Business Research, 67: 641-647

[33] Grullon, G., Michaely, R. and Swaminathan, B. (2002). Are Dividend Changes A Sign of Firm Maturity? Journal of Business, 75, 387-424. 
[34] Greiner, A. Kohlbeck, M. J. and Smith, T.J. (2017). The Relationship between Aggressive Real Earnings Management and Current and Future Audit Fees. Auditing-A Journal Of Practive \& Theory, 36(1): 85-107.

[35] Haga, J. Hoglund, H. and Sundvik, D.(2018). Stock market listing status a-nd real earnings management. Journal of Accoutning and Public Policy, 37(5):420-435.

[36] Halaoua,S.,Hamdi,B. and Mejri,T. (2017). Earnings management to exceed thresholds in continental and Anglo-Saxon accounting models: The British and French cases. Research in International Business and Finance,39:513-529.

[37] Healy, P.M. and Wahlen, J.M.(1999).A Review of the earnings management literature and its implications for standard setting. Accounting Horizons, 13(4):365-383.

[38] Ho, LC.J., Liao, Q. and Taylor, M. (2015).Real and Accrual-Based Earnings Management in the Pre- and Post-IFRS Periods: Evidence from China. Journal of International Financial Management \& Accoutning, 26( 3):294-335

[39] Huang, K. Lao, B. and McPhee, G. (2017). Does Stock Liquidity Affect Accrual-based Earnings Management. Journal of Business Finacne \& Accounting, 44(3-40):417-447.

[40] Ifada,L.M. and Wulandari, N.(2015). The Effect of Deferred Tax and Tax Planning Toward Earnings Management Practice: An Empirical Study on Non Manufactring Companies Listed In Indonesia Stock Exchange In The Period of 2008-2012. The International Journal of Organizational Innovation, 8(1): $155-170$

[41] Kahneman, D. and Tversky, A.(1979). Prospect theory: an analysis of decision under risk. Econometrica, 47: 263-291.

[42] Kallapur, S. (1994). Dividend payout ratios as determinants of earnings response coefficients: A test of the free cash flow theory. Journal of Accounting \& Economics 17: 359-375.

[43] Kasanen, E., J. Kinnunen and J. Niskanen. (1996). Dividend-based earnings management: Empirical evidence from Finland. Journal of Accounting \& Economics 22: 283-312.

[44] Kent, R. and Routledge, J.(2017). Use of benchmarks in predicting earnings management. Accounting and Finance,57(1):239-260.

[45] Kim, S.In, Byun, J.H. and Shin, H.J.(2018).Largest Shareholder Ownership and Downward Real-activity Earnings Management in Korean Seasoned Equity Offerings Firms. Aisa-Pacific Journal of Financial Studies, 47(4):546570.

[46] Kuang, Y.F., Qin, B. and Wielhouwer, J.L.(2014). CEO Origin and Accrua-1Based Earnings Management.Accounting Horizons, 28( 3):605-626.

[47] Li, S.F.(2010). Determinants of management's preferences for an earnings threshold. Review of Accounting and Finance, 9(1):33- 49.

[48] Li,L.(2019) Is there a trade-off between accrual-based and real earnings management? Evidence from equity compensation and market pricing. Finance Research Letters, 28:191-197. 
[49] Lie, E. (2005). Financial flexibility, performance, and the corporate payout choice. Journal of Business 78 (6): 2179-202.

[50] Lie, E. (2005). Operating performance following dividend decreases and omissions. Journal of Corporate Finance 12 (1): 27-53.

[51] Lintner, J. (1956). Distribution of incomes of corporations among dividends, retained earnings, and taxes. American Economic Review, 46(2):97-113.

[52] Liu, N. and Espahbodi.R.(2014). Does dividend policy drive earnings smoothing? Accounting Horizons, 28(3): 501-528

[53] Liu, F. , Du, J. and Bian, C. (2019). Don't Touch My Cheese: Short Sellin-g Pressure, Executive Compensation Justification, and Real Activity Earnings Management. Emerging Markets Fiance and Trade , 55(9):1969-1990.

[54] Liu, M. H. C.,Tiras, S.L. and Zhuang, Z. (2014). Audit committee accounting expertise, expectations management, and nonnegative earnings surprises. Journal of Accounting and Public Policy 33( 2):145-166.

[55] Macgregor, J. (2012).Audit committee equity holdings, the risk of reporting problems, and the Achievement of earnings thresholds. Journal of Accounting and Public Policy, 31:471-491.

[56] Namazi M (1985). Theoretical developments of principal-agent employment contract in accounting: the state of the art. Journal of Accounting Literature, 4:113-163.

[57] Meini, Z. and Siregar, S.V. (2014). The effect of accrual earnings management and real earnings management on earnings persistence and cost of equity. Journal of Economics, Business, and Accountancy Ventura, 17(2):269-280

[58] Mellado-Cid,C. Jory,S.R. and Ngo, T.N. (2019). Options trades, short sales and real earnings management. Accoutning and Business Research , 49( 4): 400-427.

[59] Mellado-Cid, C. Jory, S.R. and Thanh, N. (2017). Real earnings managemen$\mathrm{t}$ activities prior to bond issuance. BRQ-Business Research Quarterly, 20(3):164-177.

[60] Miller, M. and F. Modigliani. (1961). Dividend policy, growth and the valuation of shares. The Journal of Business 34: 411-433.

[61] Pham,H.Y, Chung,R.Yiu-Ming and Eduardo, R. (2019). Discretionary accrual-s: signalling or earnings management in Australia? Accounting and Financ-e, 5(2): 1383-1413.

[62] Razzaque, R.R., Ali, M.J. and Mather, P.R. (2016). Real earnings management in family firms: Evidence from an emerging economy. Pacific-Basin Finance Journal, 40(SI): 237-250.

[63] Roychowdhury, S(2006). Earnings management through real activities manipulation. Journal of Accounting and Economics, v.42, n.3, p, 335-370.

[64] Shu, P.G. and Chiang, S.J. (2014).Firm size, timing, and earnings management of seasoned equity offerings. International Review of Economics and Finance, 29:177-194.

[65] Shao, L., Kwok, C.C. and Guedhami, O.(2009). National culture and dividend policy. Journal of International Business Studies 41, 1391-1414 
[66] Stubben,S.R.(2010).Discretionary revenues as a measure of earnings management. Accounting Review 85 (2):695-717.

[67] Taj,S.A. (2016). Application of signaling theory in management research: Addressing major gaps in theory European Management Journal,34:338-348.

[68] Watts, R. and Zimmerman, J.(1986). Positive Accounting Theory. Prentice Hall, Englewood Cliffs, NJ.

[69] Zhu, T., Lu, M. and Shan, Y. (2015). Accrual-based and real activity earnings management at the back door: Evidence from Chinese reverse merger-s. Pacific-Basin Finance Journal,35: 317-339. 